\title{
Efficacy and tolerability of 12-weeks treatment with lipanthyl supra or trichol in Indonesian patients with dyslipidemia
}

\author{
Siti Fadilah Supari, Sunu Budhi Raharjo, Lies Dina Liastuti, Adnil Basha
}

\begin{abstract}
Abstrak
Hubungan antara dislipidemia dengan terjadinya aterosklerosis dan penyakit jantung koroner sudah terbukti dalam banyak studi. Penelitian ini bertujuan mengevaluasi perubahan kadar lipid setelah pemberian fenofibrat produksi lokal (trichol) atau lipanthyl supra pada pasien dislipidemia di RSJPD Harapan Kita secara teracak (randomized) dan tersamar (double-blinded). Sebanyak 68 pasien dengan kadar HDL $\leq 40 \mathrm{mg} / \mathrm{dL}$; trigliserida $200-600 \mathrm{mg} / \mathrm{dl}$; dan/atau LDL $\geq 130 \mathrm{mg} / \mathrm{dL}$ diikutsertakan sebagai subyek penelitian. Subyek dirandomisasi untuk mendapatkan lipanthyl $160 \mathrm{mg}$ satu kali/hari atau trichol $300 \mathrm{mg}$ satu kali/hari. 61 pasien mengikuti uji klinik ini sampai selesai. Kadar lipid sebelum terapi (data dasar) dan 4, 8, 12 minggu setelah terapi diperiksa dan dianalisis. Dibandingkan dengan data dasar, terapi selama 12 minggu mampu meningkatkan kadar HDL sebesar 18.8\% dan $14.3 \%(P<0.001)$, menurunkan kadar trigliserida sebesar 38.2\% dan 37.2\% ( $P<0.001)$, meningkatkan kolesterol total sebesar $3.1 \%(P=0.114)$ dan $8.4 \%$ $(P<0.005)$, menurunkan rasio kolesterol total/HDL sebesar $17.6 \%$ dan $18.4 \%(P<0.001)$, meningkatkan ApoA-1 sebesar $15.0 \%$ dan 9.7\% dan menurunkan kadar fibrinogen sebesar $13.8 \%$ dan $6.4 \%$ untuk lipanthyl dan trichol. Tidak ada perbedaan yang bermakna pada kadar LDL untuk kedua grup. Hal yang menarik adalah trichol mampu menurunkan tingkat kolesterol total $(P<0.05)$ lebih baik dibanding lipanthyl. Efek samping yang diakibatkan oleh kedua perlakuan tidak berbeda bermakna. Terapi dengan trichol dan lipanthyl mampu memperbaiki kadar lipid pasien dislipidemia. Kedua obat meningkatkan kadar HDL dan menurunkan kadar trigliserida secara bermakna. Selain itu, penurunan kadar kolesterol total secara bermakna dapat dicapai setelah 12 minggu terapi dengan trichol tetapi tidak dengan lipanthyl. (Med J Indones 2007; 16:159-67)
\end{abstract}

\begin{abstract}
The relation of dyslipidemia with the development and progression of atherosclerosis and coronary artery diseases has been demonstrated. This study compared the lipid modifying effects of locally-manufactured fenofibrate (trichol) versus lipanthyl supra in a randomized double-blind controlled study. A total of sixty-eight patients with levels of HDL cholesterol $\leq 40 \mathrm{mg} / \mathrm{dL}$; triglyceride of 200-600 $\mathrm{mg} / \mathrm{dL}$; or $L D L$ of $\geq 130 \mathrm{mg} / \mathrm{dL}$ were recruited to this study and were randomized to either receive trichol $300 \mathrm{mg}$ once daily or lipanthyl $160 \mathrm{mg}$ once daily. Sixty one patients completed the study. Lipid levels before and 4, 8, and 12 weeks after the treatments were measured and analyzed. Compared to baseline values, 12-weeks treatment with either lipanthyl or trichol significantly increased plasma HDL by $18.8 \%$ and $14.3 \%$ respectively $(P<0.001)$, decreased triglyceride by $38.2 \%$ and $37.2 \%(P<0.001)$, but with no significant change in LDL levels. Furthermore, we observed a decreased in total cholesterol levels compare to baseline by $8.4 \%$ $(P<0.05)$ and $3.1 \%(P=0.114)$, in total cholesterol/ HDL ratio by $17.6 \%$ and $18.4 \%(P<0.001)$, in fibrinogen level by $13.8 \%$ and $6.4 \%$ and an increase in ApoA-1 by 15.0\% and 9.7\% for lipanthyl and trichol, respectively. Interestingly, the decrease in total cholesterol level is significantly higher in trichol than lipanthyl groups $(P<0.05)$.The adverse events of both treatments were comparable. The lipid-modifying effects of $300 \mathrm{mg}$ daily dose of trichol is comparable to that of $160 \mathrm{mg}$ daily dose of lipanthyl. Both drugs efficiently increased the plasma HDL levels and decreased plasma triglycerides concentration. Besides, a significant reduction of total cholesterol was achieved after 12 weeks treatment with trichol, but not lipanthyl. (Med J Indones 2007; 16:159-67)
\end{abstract}

Keywords: dyslipidemia, fenofibrate

Coronary artery disease (CAD) is the leading cause of mortality worldwide. Dyslipidemia has long been recognized as one of the major risk factors for this

Department of Cardiology and Vascular Medicine, Faculty of Medicine, University of Indonesia/Cardiovascular Research Center, National Cardiovascular Center Harapan Kita, Jakarta, Indonesia disease and there has been a sharp increase in its prevalence in not only the industrialized nations, but also the developing world ${ }^{1}$. WHO-MONICA study, an epidemiological study to monitor the trend and determinants of cardiovascular diseases, have shown that the prevalence of dyslipidemia in Jakarta increased from $11.4 \%$ in 1988 to $14.65 \%$ in $2000 .^{2}$ 
Statins are an important component of care in the management of dyslipidemia, primarily due to their effectiveness in reducing low-density lipoprotein (LDL), their safety and tolerability, and because of their demonstrated ability to reduce cardiovascular morbidity and mortality. ${ }^{3}$ A recent published clinical trial of the use of statin indicated that aggressive lowering of LDL resulted in significant reduction in the rate of primary endpoints compared to the conventional therapy. Nevertheless, the incidence of residual cardiovascular disease remains significantly high even in the aggressively treated group $(22.4 \%){ }^{4}$ Accordingly, there is large interest in the therapeutic potential of targeting other lipid-related risk factors.

Although it is well established that low density lipoprotein cholesterol (LDL) is an important risk factor for CAD, increasing data shows that low levels of HDL signify an increased incidence of CAD. A low levels of HDL is the most common lipid abnormality observed in men with coronary artery disease; it is the primary lipid abnormality in approximately half of these patients. ${ }^{5}$ Furthermore, epidemiological studies indicated that a $1 \mathrm{mg} / \mathrm{dl}$ increase in the HDL cholesterol concentration is associated with a $2-3 \%$ decrease in cardiovascular risk. ${ }^{6}$ Considering the high prevalence of low HDL in the dyslipidemia and in patients with $\mathrm{CAD}$, therapeutic increases in HDL are an obvious approach to decreasing the risk of atherosclerosis.

Fibrate is one important class of lipid-lowering drug with a documented efficacy and safety to raise HDL. Fibrates exert their indirect effect on HDL levels by activating the nuclear transcription factor peroxisome proliferative activated receptor- $\alpha$ (PPAR- $\alpha$ ). They increase HDL levels and decrease triglyceride without having a major effect on LDL levels. However, those beneficial effects are mainly demonstrated for Caucasian. To the best of our knowledge, however, the efficacy and tolerability of these regimens have not been analyzed in Indonesian population with dyslipidemia. It is important to note that the ethnic difference and genetic predisposition have been shown to contribute to the response of therapy toward lipid-lowering drug. ${ }^{7}$ Therefore, this study was designed to assess the efficacy and tolerability of fenofibrates in a randomizedcontrolled study in Indonesian subjects.

\section{METHODS}

\section{Patients}

Patients of either sex aged between 25 and 70 years with dyslipidemia were eligible if they did not take any other lipid lowering drugs before and during the treatment and have one of any of the folowing conditions: 1) levels of HDL cholesterol $<40 \mathrm{mg} / \mathrm{dL}$; 2) triglyceride of $200-600 \mathrm{mg} / \mathrm{dL}$; 3) LDL > $130 \mathrm{mg} / \mathrm{dL}$ ). Patients with hypothyroidism, poor-controlled diabetes mellitus, renal or liver dysfunction, cancer, cholestasis, pancreatitis, and women in pregnancy, lactation or with oral contraceptive uses were excluded. All subjects provided written consent, and the study was approved by the Ethics Committee of The National Cardiovascular Center Harapan Kita.

\section{Study Design}

This was a randomized, double-blind, controlled trial. Eligible patients entered a 2 -week run-in wash-out period followed by 12 weeks of active treatments. Sixty-eight subjects were randomized into two parallel treatment groups, 34 patients received lipantil (160 mg once a day) and 34 patients received trichol (300 mg once a day). Routine visits to the Research Center, National Cardiovascular Center Harapan Kita were scheduled monthly for clinical and adverse events evaluation, study medication distribution and compliance assesment by tablet count. Advice was given to continue isocaloric diet and maintain physical activity constant. Labeling and sealing of medicines were performed by the manufacturer under the supervision of the staff from the Research Center. Among 68 enrolled patients (intention-to-treat), 61 patients completed the trial. There are four drop-out cases in lipanthyl group and three dropout cases in trichol group. Of these drop-out cases, 2 in lipanthyl group and 1 in trichol group were ascribed to drugrelated side effects; whereas 2 in lipanthyl group and 2 in trichol group were due to poor compliance.

\section{Laboratory Methods}

Blood samples were collected using standardized equipments and procedures and were then transferred in cooled containers to the Clinical Laboratory, National Cardiovascular Center Harapan Kita, Jakarta. Blood samples were drawn after $\geq 12$ hours of fasting to determine plasma levels of cholesterol, HDL, LDL, triglycerides, plasma fibrinogen, ApoA1, glucose and creatine kinase. Whereas blood samples for the safety variables (ureum, creatinine, BUN, SGOT and SGPT) were drawn without prior fasting. Laboratory measurements were performed using standard automated procedures with commercially available kits.

\section{Statistical analysis}

Data were analyzed using SPSS software. Baseline characteristics in the 2 study groups were compared 
using the $\chi^{2}$-test for dichotomous parameters and the $t$ test for continuous variables. The ANOVA time series were used to analyze the different within each treatment between the end of the 4,8 , and 12 -weeks treatment and at the corresponding baseline levels (measured before the administration of the study medication) for each lipid profile. An unpaired t-test was conducted to test difference of each lipid profiles between lipanthyl supra dan trichol group.

\section{RESULTS}

Of the total 64 patients enrolled, 49 were men (64\%). The mean age in the lipanthyl group was $52 \pm 2$ years and in the trichol group was $55 \pm 2$ years. The baseline characteristics of all patients are shown in table 1. Except the diabetic state and the body mass index (BMI), patients in the trichol $(n=34)$ and lipanthyl $(n=34)$ groups were balanced in terms of clinical and laboratory baseline characteristics (Table 1). Lipid profiles were similar in the patients in the two groups at the time of randomization.

The study lasted for 12 weeks and by the end of the study 4 patients $(11.8 \%)$ in lipanthyl group and 3 patients $(8.8 \%)$ in trichol group were dropped out from the study. Reasons for discontinuation of study medication were ascribed to drug-related side effects ( 2 in lipanthyl group and 1 in trichol group); whereas 2 patients in lipanthyl group and 2 in trichol group request to discontinue study medication. Thus, 30 patients in lipanthyl group and 31 patients in trichol group completed the entire study. Compliance, according to the tablet counts, exceeded $90 \%$ in both groups.

Table 1. Demographic and Laboratory Characteristics of the Two Study Groups

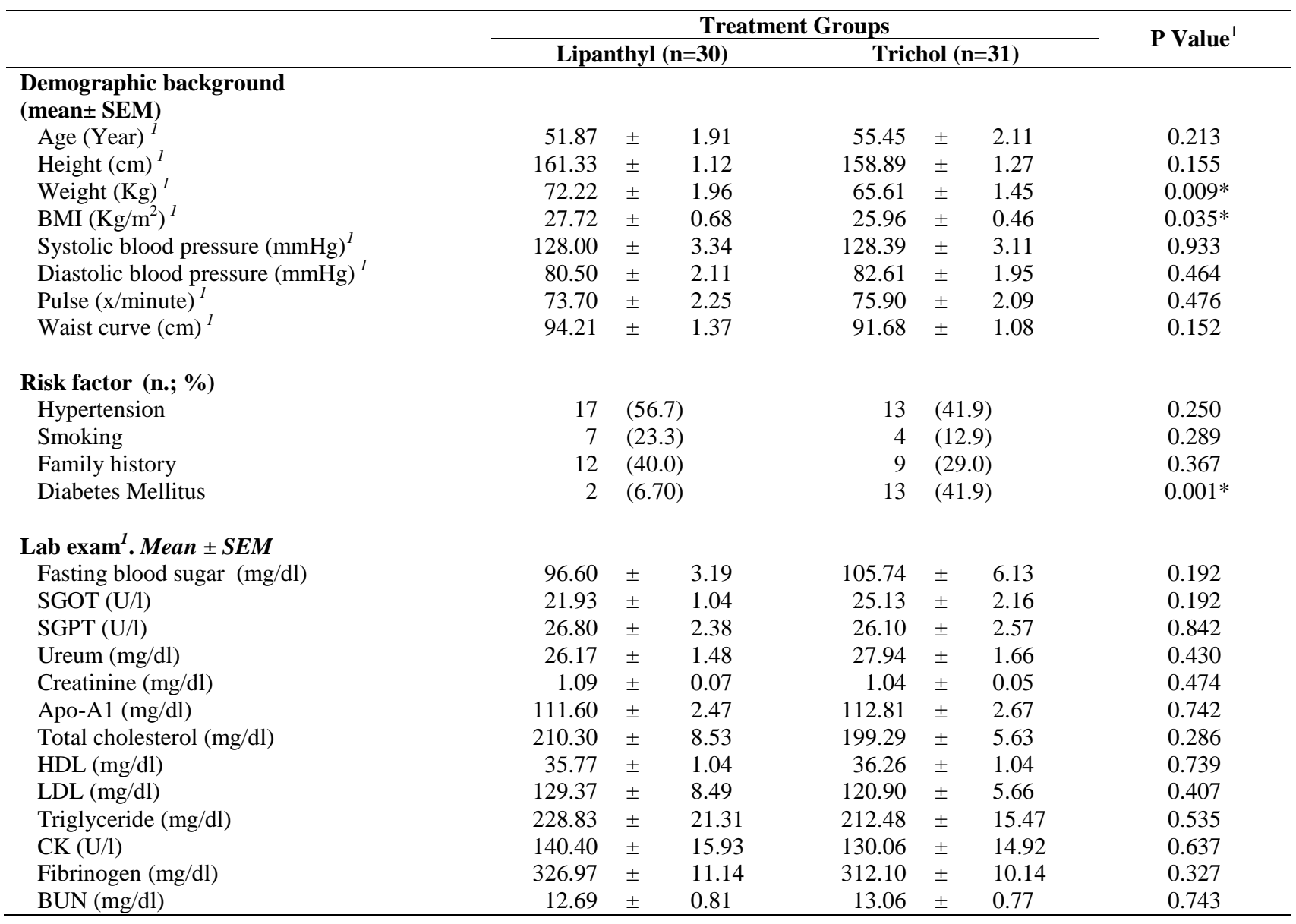

* significant. ${ }^{1}$ Independent $t$-test. ${ }^{2}$ Chi-square 


\section{Effect of treatment on lipid profiles}

Figure 1 showed that at 4 weeks, plasma triglyceride levels had decreased significantly in both treatment groups and remained significantly lower at 12 weeks. At the same time, the levels of HDL cholesterol had increased at 4 weeks of treatments in both groups of patients. These increases persisted till the end of follow up period (12 weeks).

The average changes in lipid parameters are shown in figure 2 . The most marked changes were a reduction of $38.2 \%$ and $37.2 \%$ in triglycerides and an increase of $18.8 \%$ and $14.3 \%$ in HDL levels for lipanthyl and trichol groups, respectively. Interestingly, we observed significant reductions in levels of total cholesterol in trichol group, but not lipanthyl. No significant change were observed in the LDL cholesterol concentration. Both treatments significantly rose the plasma ApoA1 and decreased fibrinogen levels at 12 weeks.

HDL

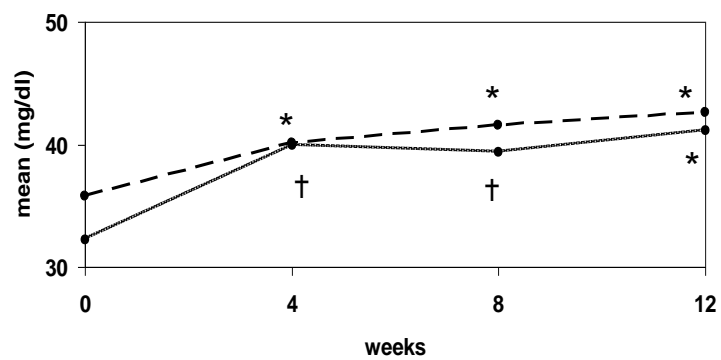

Triglyceride

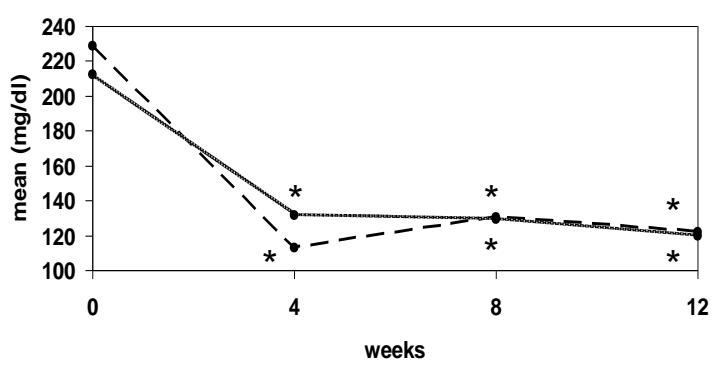

${ }^{\dagger} \mathrm{P}<0.05$ vs. baseline value ${ }^{*} \mathrm{P}<0.001$ vs. baseline value

\section{Treatment effects in the different subgroups}

Since the proportion of patients with diabetes mellitus were different between the two groups, we performed a separate analysis of patients without diabetes $(n=28$ in lipanthyl and $n=18$ in trichol). Our results indicated that the percent changes on lipid profiles among nondiabetic patients were similar with that of total population (diabetic and non-diabetic combined) (table 2).

We also performed analysis of group of patients with BMI $<25 \mathrm{~kg} / \mathrm{m} 2$ (normoweight) and BMI $\geq 25 \mathrm{~kg} / \mathrm{m} 2$ (overweight and obese) separately to assess whether drug effects were similar in comparison with the overall study population. Among normoweight patients, the changes in lipid profiles between the two groups of treatment were quite similar. The effect of trichol therapy was more pronounced in those with BMI $\geq 25 \mathrm{~kg} / \mathrm{m} 2$ as indicated by the lower levels of LDL cholesterol at 12 weeks compared to lipanthyl group $(\mathrm{P}<0.05)$ (table 3 and 4$)$.

\section{Total cholesterol}

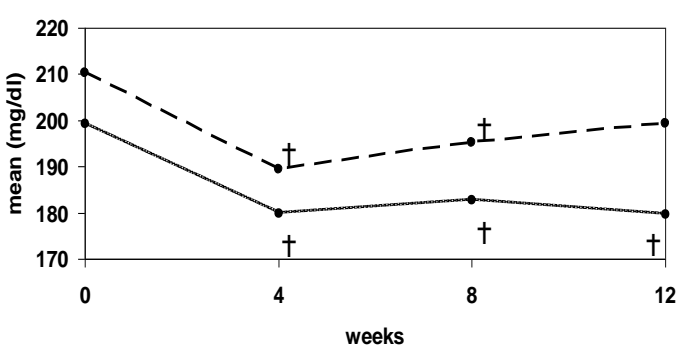

LDL

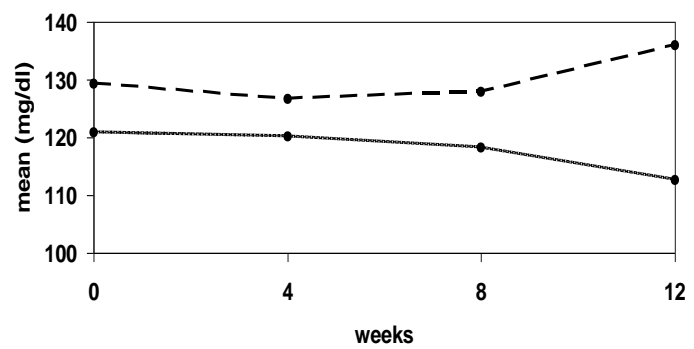

$$
\begin{array}{cl}
\text { - - - : Lipanthyl } \\
\text { _ : Trichol }
\end{array}
$$

Figure 1. Changes in Lipid Values Throughout the Study Period 


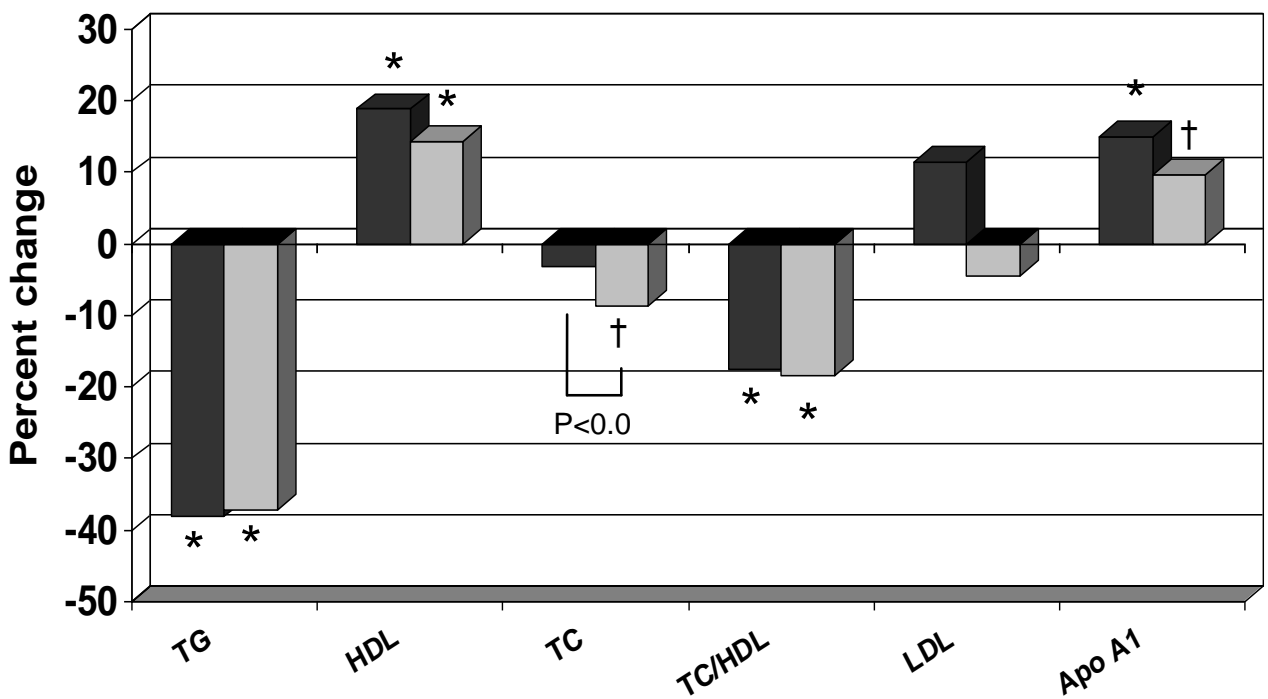

TG: triglyceride, HDL: high density lipoprotein, LDL: high density lipoprotein, TC: total cholesterol, TC/HDL: total cholesterol/high density lipoprotein, LDL: low density lipoprotein

${ }^{\dagger} \mathrm{P}<0.05$ vs. baseline value, ${ }^{*} \mathrm{P}<0.001$ vs. baseline value

Figure 2. Percent of changes in lipid values in two groups of treatment

Table 2. The Lipid Profiles in Non-Diabetic Patients

\begin{tabular}{|c|c|c|c|}
\hline & $\begin{array}{c}\text { Lipanthyl }^{1} \\
(\mathrm{n}=28)\end{array}$ & $\begin{array}{c}T^{\text {Trichol }} \\
(\mathrm{n}=18)\end{array}$ & P Value \\
\hline \multicolumn{4}{|c|}{ Total Cholesterol (mg/dl) } \\
\hline Baseline & $211 \pm 9.0$ & $193 \pm 5.3$ & 0.09 \\
\hline 12 weeks treatment & $201 \pm 7.5$ & $178 \pm 4.9$ & $0.01^{\dagger}$ \\
\hline Change $(\%)$ & $-2.6^{\mathrm{NS}}$ & $-7.3^{\dagger}$ & \\
\hline \multicolumn{4}{|c|}{ LDL-Cholesterol (mg/dl) } \\
\hline Baseline & $129 \pm 9.1$ & $120 \pm 5.3$ & 0.40 \\
\hline 12 weeks treatment & $137 \pm 7.5$ & $114 \pm 4.4$ & $0.01^{\dagger}$ \\
\hline Change $(\%)$ & $13^{\mathrm{NS}}$ & $-3.3^{\mathrm{NS}}$ & \\
\hline \multicolumn{4}{|l|}{ Triglyceride (mg/dl) } \\
\hline Baseline & $235 \pm 22.1$ & $196 \pm 19.0$ & 0.21 \\
\hline 12 weeks treatment & $121 \pm 14.0$ & $114 \pm 10.1$ & 0.70 \\
\hline Change $(\%)$ & $-40.1^{*}$ & $-36.7 *$ & \\
\hline \multicolumn{4}{|l|}{ HDL-Cholesterol } \\
\hline Baseline & $36 \pm 1.1$ & $36 \pm 1.1$ & 0.81 \\
\hline 12 weeks treatment & $43 \pm 1.1$ & $42 \pm 1.5$ & 0.56 \\
\hline Change (\%) & $19.8^{*}$ & $16.5^{*}$ & \\
\hline \multicolumn{4}{|c|}{ Total Cholesterol/HDL ratio } \\
\hline Baseline & $6 \pm 0.3$ & $5 \pm 0.2$ & 0.12 \\
\hline 12 weeks treatment & $5 \pm 0.2$ & $4 \pm 0.2$ & 0.16 \\
\hline Change (\%) & $-17.8^{*}$ & $-19.4 *$ & \\
\hline \multicolumn{4}{|l|}{ Apo-A1 } \\
\hline Baseline & $111 \pm 2.6$ & $0.3 \pm 0.01$ & 0.88 \\
\hline 12 weeks treatment & $127 \pm 2.9$ & $0.4 \pm 0.03$ & 0.15 \\
\hline Change (\%) & $15.3 *$ & $13.6^{\dagger}$ & \\
\hline
\end{tabular}

\footnotetext{
${ }^{1}$ The value is mean \pm SEM (Standard error of mean),${ }^{\dagger} \mathrm{P}$ value $<0.05, * \mathrm{P}$ value $<0.001,{ }^{\text {NS }}$ Not significant
} 
Table 3. The Lipid Profiles in Patients with BMI $<25 \mathrm{~kg} / \mathrm{m}^{2}$

\begin{tabular}{|c|c|c|c|}
\hline & $\underbrace{\text { Lipanthyl }^{I}}_{(n=6)}$ & $\begin{array}{c}\text { Trichol }^{\mathrm{I}} \\
(\mathrm{n}=11)\end{array}$ & P Value \\
\hline \multicolumn{4}{|c|}{ Total Cholesterol (mg/dl) } \\
\hline Baseline & $214 \pm 13.0$ & $190 \pm 9.3$ & 0.16 \\
\hline 12 weeks treatment & $205 \pm 23.6$ & $174 \pm 7.5$ & 0.26 \\
\hline Change $(\%)$ & $-4.9^{\mathrm{NS}}$ & $-7.7^{\mathrm{NS}}$ & \\
\hline \multicolumn{4}{|c|}{ LDL-Cholesterol (mg/dl) } \\
\hline Baseline & $119 \pm 6.3$ & $122 \pm 8.3$ & 0.81 \\
\hline 12 weeks treatment & $144 \pm 23.2$ & $112 \pm 6.0$ & 0.23 \\
\hline Change $(\%)$ & $20.3^{\mathrm{NS}}$ & $-5.8 \mathrm{NS}$ & \\
\hline \multicolumn{4}{|l|}{ Triglyceride (mg/dl) } \\
\hline Baseline & $305 \pm 64.5$ & $182 \pm 22.6$ & $0.04^{\top}$ \\
\hline 12 weeks treatment & $96 \pm 21.9$ & $111 \pm 11.3$ & 0.50 \\
\hline Change $(\%)$ & $-64.8^{\top}$ & $-32.4^{\top}$ & \\
\hline \multicolumn{4}{|l|}{ HDL-Cholesterol } \\
\hline Baseline & $36 \pm 1.9$ & $35 \pm 1.6$ & 0.73 \\
\hline 12 weeks treatment & $42 \pm 2.4$ & $41 \pm 1.9$ & 0.58 \\
\hline Change $(\%)$ & $18.8^{\mathrm{NS}}$ & $15.9^{\top}$ & \\
\hline \multicolumn{4}{|c|}{ Total Cholesterol/HDL ratio } \\
\hline Baseline & $6 \pm 0.4$ & $6 \pm$ & 0.30 \\
\hline 12 weeks treatment & $5 \pm 0.5$ & $4 \pm 0.2$ & 0.32 \\
\hline Change $(\%)$ & $-18.5^{\top}$ & $-19.1^{\top}$ & \\
\hline \multicolumn{4}{|l|}{ Apo-A1 } \\
\hline Baseline & $116 \pm 7.9$ & $0.4 \pm 0.02$ & 0.74 \\
\hline 12 weeks treatment & $130 \pm 6.8$ & $0.4 \pm 0.03$ & 0.35 \\
\hline Change $(\%)$ & $14.4^{\mathrm{NS}}$ & $9.9^{\top}$ & \\
\hline
\end{tabular}

${ }^{1}$ The value is mean $\pm \mathrm{SEM},{ }^{\dagger} \mathrm{P}$ value $<0.05$, $* \mathrm{P}$ value $<0.001,{ }^{\mathrm{NS}}$ Not significant

Table 4. The Lipid Profiles in Patients with BMI $\geq 25 \mathrm{~kg} / \mathrm{m}^{2}$

\begin{tabular}{|c|c|c|c|}
\hline & $\begin{array}{c}\text { Lipanthyl }^{\mathrm{T}} \\
(\mathrm{n}=\mathbf{2 4})\end{array}$ & $\begin{array}{c}\text { Trichol }^{T} \\
(\mathbf{n}=\mathbf{2 0})\end{array}$ & P Value \\
\hline \multicolumn{4}{|c|}{ Total Cholesterol (mg/dl) } \\
\hline Baseline & $209 \pm 10.3$ & $204 \pm$ & 0.66 \\
\hline 12 weeks treatment & $198 \pm 7.0$ & $183 \pm$ & 0.13 \\
\hline Change (\%) & $-2.7^{\mathrm{NS}}$ & $-8.7^{\top}$ & \\
\hline \multicolumn{4}{|c|}{ LDL-Cholesterol (mg/dl) } \\
\hline Baseline & $132 \pm 10.5$ & $120 \pm$ & 0.39 \\
\hline 12 weeks treatment & $134 \pm 7.0$ & $113 \pm 7.4$ & $<0.05^{\top}$ \\
\hline Change $(\%)$ & $9.2^{\mathrm{NS}}$ & $-3.7^{\mathrm{NS}}$ & \\
\hline \multicolumn{4}{|l|}{ Triglyceride (mg/dl) } \\
\hline Baseline & $210 \pm 20.3$ & $230 \pm$ & 0.49 \\
\hline 12 weeks treatment & $129 \pm 16.0$ & $125 \pm 10.3$ & 0.84 \\
\hline Change $(\%)$ & $-31.5^{\top}$ & $-40.0 *$ & \\
\hline \multicolumn{4}{|l|}{ HDL-Cholesterol } \\
\hline Baseline & $36 \pm 1.2$ & $37 \pm$ & 0.54 \\
\hline 12 weeks treatment & $43 \pm 1.2$ & $42 \pm$ & 0.56 \\
\hline Change $(\%)$ & $18.8 *$ & $13.4^{\top}$ & \\
\hline \multicolumn{4}{|c|}{ Total Cholesterol/HDL ratio } \\
\hline Baseline & $6 \pm 0.3$ & $6 \pm$ & 0.38 \\
\hline 12 weeks treatment & $5 \pm 0.2$ & $5 \pm$ & 0.56 \\
\hline Change $(\%)$ & $-17.3 *$ & $-17.9^{\top}$ & \\
\hline \multicolumn{4}{|l|}{ Apo-A1 } \\
\hline Baseline & $111 \pm 2.4$ & $0.3 \pm$ & 0.49 \\
\hline 12 weeks treatment & $126 \pm 3.0$ & $0.4 \pm 0.04$ & 0.09 \\
\hline Change $(\%)$ & $15.1 *$ & $9.6^{\top}$ & \\
\hline
\end{tabular}

${ }^{1}$ The value is mean $\pm \mathrm{SEM},{ }^{\dagger} \mathrm{P}$ value $<0.05, * \mathrm{P}$ value $<0.001,{ }^{\mathrm{NS}}$ Not significant 


\section{Safety}

The overall incidence of any adverse event was higher in the trichol than lipanthyl groups (table 6). Statistically, however, the frequency of each adverse event was not different between the two groups. Ten patients in the trichol group and 7 patients in the lipanthyl group complained of chest discomfort; and 4 patients in the trichol group and 3 patients in the lipanthyl group complained of dizziness. For the laboratory parameters of drug safety, no significant differences were observed between the two study groups (table 5).

Table 5. Possible drug-related side effects in total population of patients

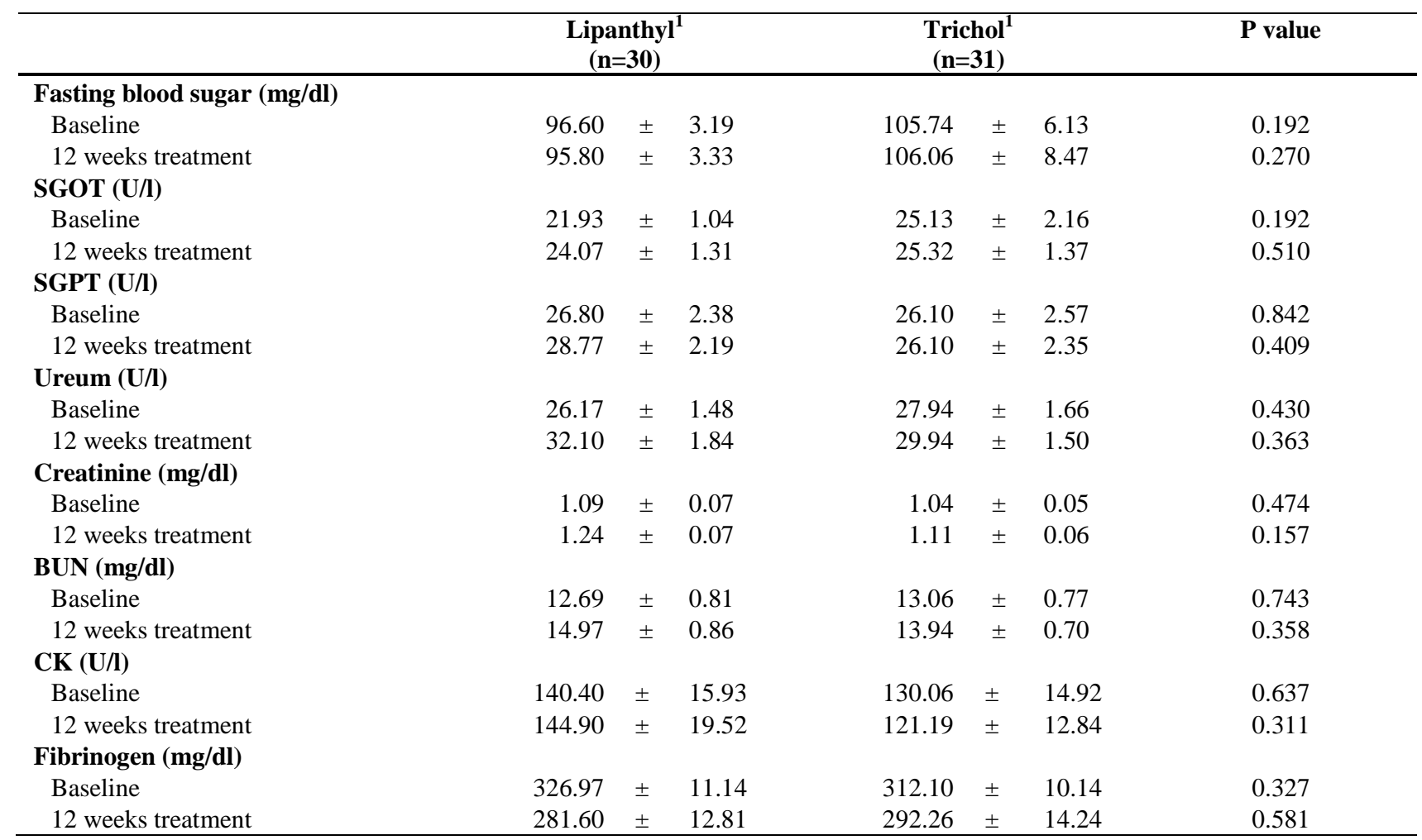

${ }^{1}$ The value is mean \pm SEM

Table 6. Observed adverse event during 12 weeks treatment on patients

\begin{tabular}{|c|c|c|c|c|c|}
\hline \multirow[b]{3}{*}{ Chest discomfort } & \multicolumn{4}{|c|}{ Treatment group } & \multirow{3}{*}{$\begin{array}{c}\text { P value }^{l} \\
0.400\end{array}$} \\
\hline & \multicolumn{2}{|c|}{$\begin{array}{c}\text { Lipanthyl } \\
(n=34)\end{array}$} & \multicolumn{2}{|c|}{$\begin{array}{l}\text { Trichol } \\
(n=34)\end{array}$} & \\
\hline & 7 & 20.6 & 10 & 29.4 & \\
\hline Palpitation & 2 & 5.9 & 2 & 5.9 & 1.000 \\
\hline Back neck stiffness & 0 & 0.0 & 2 & 5.9 & 0.920 \\
\hline Cold sweat & 0 & 0.0 & 2 & 5.9 & 0.493 \\
\hline Coughing & 0 & 0.0 & 3 & 8.8 & 0.239 \\
\hline Nausea & 2 & 5.9 & 2 & 5.9 & 1.000 \\
\hline Fatigue & 2 & 5.9 & 4 & 11.8 & 0.673 \\
\hline Dizziness & 3 & 8.8 & 4 & 11.8 & 1.000 \\
\hline
\end{tabular}




\section{DISCUSSION}

The main result of our study is that 12 weeks treatment with lipanthyl and the locally-manufactured fenofibrate (trichol) are effective to induce the expected modifications of plasma lipid levels. Both therapies resulted in a large decrease of triglyceride concentration, an increase of HDL cholesterol, a moderate fall of total cholesterol levels and a significant reduction of total cholesterol / HDL ratio. Furthermore, both fibrates were able to lower the plasma fibrinogen levels. These results demonstrated that both lipanthyl and trichol beneficially modified the lipid profile of Indonesian patients with atherogenic dyslipidemia.

Data from clinical trials indicated that therapy with fenofibrate is beneficial in both primary and secondary preventions. The Veterans Affairs High-Density Lipoprotein Intervention Trial (VA-HIT) showed that treatment with fibrate (gemfibrozil) in patients with low HDL and mildly elevated triglyceride levels resulted in a significant elevation in HDL cholesterol and a reduction in triglycerides, with no change in LDL cholesterol, that coincided with a significant reduction in the CAD event rate $(22 \%) .{ }^{8}$ On the other hand, the Diabetes Atherosclerosis Intervention Study (DAIS) and the Bezafibrate Infarction Prevention (BIP) study showed that treatment with fibrates induced a significant reduction in the primary study end points, which were related to significant reductions in triglycerides and increases in HDL cholesterol, accompanied by a small decrease in LDL cholesterol. ${ }^{9,10}$ The VA-HIT and BIP studies enrolled subjects with and without diabetes mellitus while the DAIS only recruited diabetic patients. The characteristics of patients in this study also reflected the conditions of atherogenic dyslipidemia, and both fenofibrates used in this study induced an increase of HDL cholesterol and a reduction in TG levels higher than that of VA-HIT, BIP and DAIS trials. Therefore, we suppose that the use of these regiments will translate into analogous clinical benefit.

The identification of PPAR transcription factors as the main pathway of the mechanism of action of fibrates and glitazones has generate big interest in the antiatherogenic effects of these agents. However, unlike the glitazones that act as high affinity agonists by directly binding to PPAR- $\gamma$, fibrates are comparatively week agonists of PPAR- $\alpha$ and do not show a high degree of subtype selectivity. ${ }^{11}$ Therefore, it is logical that the dose of glitazone used to activate PPAR- $\gamma$ (15 - $30 \mathrm{mg}$ per day) is much lower than the dose of fibrate needed to produce its action $(200-1,200 \mathrm{mg}$ per day). Indeed, several trials used diverse doses of fibrates to improve lipid profiles. For example, ciprofibrate was administered as $100 \mathrm{mg} / \mathrm{d},{ }^{12}$ fenofibrate as $200-300 \mathrm{mg} / \mathrm{d},{ }^{13,14}$ bezafibrate as $400-600 \mathrm{mg} / \mathrm{d}$, gemfibrozil as $1,200 \mathrm{mg} / \mathrm{d}$, and clofibrate as 2,000 $\mathrm{mg} / \mathrm{d}^{15}$ The difference in the dosing is highly determined by the affinity of those compound to PPAR- $\alpha$. Accordingly, we believe that the different dose of trichol $(300 \mathrm{mg} / \mathrm{d})$ and lipanthyl supra (160 $\mathrm{mg} / \mathrm{d}$ ) used in this study is mainly due to their dissimilar affinity to PPAR- $\alpha$ due to the difference in their structure, in which lipanthyl supra is not only micronized but also micro-coated so that their bioavailability is better than trichol. Nevertheless, their efficacy and tolerability are comparable.

\section{CONCLUSIONS}

Trichol was found to be safe and as effective as lipanthyl in elevating HDL cholesterol and lowering triglycerides in Indonesian subjects with dyslipidemia. Although there are some clinical complains, these complains are mild, transient and tolerable trough the study period. On the basis of cost-effectiveness toward drug therapies, trichol and lipanthyl are recommended as good choices for atherogenic dyslipidemia in Indonesian populations.

\section{Acknowledgements}

We thank all participating subjects and all staffs of Cardiovascular Research Center Harapan Kita. We also would like to acknowledge Prof. Dr. Bambang Sutrisna, MHSc for his advices on statistics and PT. Galenium Pharmacia Laboratories for their financial support.

\section{REFERENCES}

1. Murray CJ, Lopez A. D. Mortality by cause for eight regions of the world: Global Burden of Disease Study. Lancet. 1997; 349:1269-76.

2. Supari F. Profil Lipid Plasma pada MONICA III Tahun 2000. Kumpulan Makalah Seminar Sehari Presentasi Hasil MONICA - Jakarta III. 2000.

3. Heart Protection Study Collaborative Group. MRC/BHF Heart Protection Study of cholesterol lowering with simvastatin in 20,536 high-risk individuals: a randomized placebo-controlled trial. Lancet. 2002; 360: 7-22.

4. Cannon $\mathrm{CP}$ et al. Intensive versus moderate lipid lowering with statins after acute coronary syndromes. N Engl J Med. 2004; 350:1495-504. 
5. Genest JJ, McNamara JR, Salem DN, Schaefer EJ. Prevalence of risk factors in men with premature coronary artery disease. Am J Cardiol. 1991; 67: 1185-9.

6. Assmann G, Schulte H. Relation of high-density lipoprotein cholesterol and triglycerides to incidence of atherosclerotic coronary artery disease (the PROCAM experience). Prospective Cardiovascular Munster study. Am J Cardiol. 1992; 70: 733-7.

7. Chasman DI, Posada D, Subrahmanyan L, Cook NR, Stanton VP, Ridker PM. A pharmacogenetic study of statin therapy and cholesterol reduction. JAMA. 2004; 291:2821-7.

8. Robins SJ, Collins D, Wittes JT, Papademetriou V, Deedwania PC, Schaefer EJ, McNamara JR, Kashyap ML, Hershman JM, Wexler LF, Rubins HB, VA-HIT Study Group: Relation of gemfibrozil treatment and lipid levels with major coronary events: VA-HIT: a randomized controlled trial. JAMA. 2001; 285:1585-91.

9. The Bezafibrate Infarction Prevention (BIP) Study. Secondary Prevention by Raising HDL Cholesterol and Reducing Triglycerides in Patients With Coronary Artery Disease. Circulation 2000;102:21-7.
10. Effect of Fenofibrate on Progression of Coronary-Artery Disease in Type 2 Diabetes: The Diabetes Atherosclerosis Intervention Study, A Randomized Study. Lancet. 2001;357:905-10.

11. Linsel-Nitschke P, Tall AR. HDL as A Target in The Treatment of Atherosclerotic cardiovascular Disease. Nature Review Drug Discovery. 2005;4:193-205.

12. Rizos E, Bairaktari E, Ganotakis E, Tsimihodimos V, Mikhailidis DP, Elisaf M. Effect of Ciprofibrate an Lipoprotein, Fibrinogen, Renal Function, and Hepatic Enzymes. J Cardiovasc Pharmacol Ther. 2002;4:219-26.

13. Junren Z, Ping Y. A Survey on the Efficacy and Tolerability of Micronized Fenofibrate in Patients with Dyslipidemia. Chinese Med J. 2003;116:840-3.

14. Koanantakul B, Jeamanukulkit N, Piamsomboon C, Chawantanpipat C, Khanacharoen I. Efficacy and safety of 12-week Treatment with Fenofibrate $300 \mathrm{mg}$ in Thai Dyslipidemic Patients. J Md Assoc Thai. 2004;87:1281-5.

15. Staels B, Dallongeville J, Auwerx J, Schoonjans K, Leitersdorf E, Frunchart JC. Mechanism of Action of Fibrates on Lipid and Lipoprotein Metabolism. Circulation. 1998;98:2088-93. 